\title{
FROM THEORY TO GRAND STRATEGY: ASSESSING US GOALS IN ARABIA 2001-2018
}

\author{
Ayman Saleh Al-Barasneh ${ }^{*}$
}

\begin{abstract}
The study seeks to provide an overarching understanding to the US objectives and policies in the Gulf region at three intersecting levels; strategic interests, regional security and political reform. This study takes United States interactions with Arabia, as a case study, during the period 2001-2018 under the administrations of G.W. Bush, Barack Obama and Donald Trump. Additionally, the study attempts to generate greater understanding of the dynamics that motivating American international politics and subsequent policies toward the Arab gulf countries through examining the interactions between both systematic and domestic factors. Noticeably, US entrenched vital enduring interests with the Arab Gulf States rested, for approximately seventy years, on protecting oil flow from the region into international economy without interruption, selling arms to the Gulf Arabs and maintaining gulf regional security against any real or potential threats. Therefore, the administrations of Bush, Obama, and Trump were not different from their predecessors in their strategy of preserving gulf security through forward military presence in the region. Hence, the author employs the neorealist theory to understand US interactions with the Gulf countries. Remarkably, despite some scholar's arguments that envisaged the US policies under G.W. Bush and Donald Trump as departed drastically from US conventional policy, the study argues and concludes that the US actual policy towards Arabia reflects a traditional policy of maintaining mutual interests.
\end{abstract}

Keywords: United States, foreign policy, the Arabian peninsula, the Gulf region, security, political reform, geo-political interests

\section{Introduction}

This study attempts to examine the American strategic engagement in Arabia in the period 2001-2018 with the purpose of providing an analysis relating to the US goals and policies in the region. The importance of this research stems from its discussions of the factors of continuity and change regarding US involvement in the Gulf regional affairs. As such, it elaborates on two points of view; first one, the scholars who belief that the US policy has drastically shifted from traditional policy trajectory through supporting democracy promotion and the second point of view which perceived the American policy as reflecting continuity of traditional foreign policy as oppose to change ${ }^{1}$. This argument

\footnotetext{
*Ayman Saleh Al-Barasneh, Ph.D., Assistant Professor, Political Science Department, The University of Jordan, Amman-Jordan

${ }^{1}$ Cooper, Danny. Neo-conservatism and American Foreign Policy: A Critical Analysis. (London: Rutledge, 2011).
} 
might be explained fruitfully by neorealism approach as it assumes that the US had vital geopolitical concerns in Arabia, including preserving US supremacy, protecting oil flow from the region into the international economy and countering terrorism. Remarkably, the study will demonstrate and emphasize the continuity of these hard realist interests under the administrations of Bush, Obama and Trump although the tactics and tools that used to achieve these entrenched interests might vary between the aforementioned administrations. However, the research would emphasize the overall continuity of the American objectives in the region and more importantly the continuity of conventional realist tendencies-approaches that pursued in the foreign policy from Bush to Trump.

\section{Aims and Objectives}

This research attempts to scrutinize different aspects of American engagement with Arabia during the period 2001-2018 with the objective of providing better interpretation and understanding of the US policy directions towards the region. This study seeks to answer the following two questions:

- To what extent realism retains its explanatory power as valid and relevant theory to explain and understand American interactions with the Arab gulf countries?

- What are the factors that determined the US policy attitudes in the administrations of G.W. Bush, Barack Obama and Donald Trump?

\section{Problem Definition and Argument}

Understanding foreign policy requires addressing and discussing a set of variables that contribute to the making of the foreign policy and therefore the study would concentrate on a variety of factors that played remarkable role in formulating and implementing the foreign policy agenda. The study employs neorealism approach to explaining and understanding US-Gulf relations. This approach will be used to discuss three areas; pursuing hard economic interests, maintaining the gulf regional security and pursuing low-intensity freedom agenda in the region. Remarkably, the American policy makers from Bush to Trump have realized the US unchanging economic and geopolitical interests in the gulf region and therefore they pursued a policy that encompassed less emphasized ideological elements and focused practically on realist approach that eventually dominated the foreign policy calculation and implementation. This is the case when freedom agenda is concerned and also when the security architecture and hard geopolitical interests are examined.

\section{Methodology}

The research goals will be approached and examined through providing a description and analysis to the events that impacted the US interactions in the region. Hence, the application of theoretical propositions could help in providing empirical analysis of the state action and foreign policy directions. As such, to reach the study objectives, the research uses neo-realism as theoretical framework to set up a model which used as a guide to explain continuity and overall consistency in US interactions with the gulf 
region during the time frame of the study. The importance of this analytical framework stems from its attempt to incorporate both external or systematic factors and impacts of internal or domestic factors in a formula that might be used to explaining and understanding US interactions with the gulf region.

\section{Theoretical Framework}

Realist theory explains the objectives that drive state actions in international relations. So, Hans Morgenthau- one of the prominent realists considered the main reason for conflict is the desire to dominate and therefore, he claimed that struggling for power is the main characteristic for international politics ${ }^{2}$. Moreover, the realist theory conceived nation states as the main players in international relations motivated by security and domestic interest considerations that lead eventually to the power competition ${ }^{3}$. In this context, Waltz defined realism as a process through which states seeking to adopt the policies that will achieve the state interests ${ }^{4}$. Apparently, the theory emphasizes broadly on a struggle for power and interest since states appear- like human nature - to have an insatiable appetite for gaining power. Therefore, the analysis of competing interests between states is of particular importance in the theory assumptions to understand international politics 5 . Moreover, the Realist approach perceived the international system as anarchy and therefore the main aim of state is to maintain its security and survival through power maximization policy. This motivation is useful from realist point of view to understand both domestic and international politics. Clearly, in the rivalry system states are still continue their competition for power in an attempt to increase and maximize their power as well as maintain their existence within the anarchical political system ${ }^{6}$.

Indeed, there are a variety of factors that influence collectively the American foreignpolicy outcomes and therefore, discussing the impact of events in world politics on foreign policy outcomes is of particular importance. Hence, the systematic or external factors in the international system are of particular interest to understand the US foreign policy. Furthermore, examining the domestic sources of US foreign policy is necessary to understand its contribution in the foreign policy-making process. In this regard, John Mearsheimer argues that liberal hegemony, the foreign policy pursued by the United States since the end of the Cold War would experience certain setbacks and therefore the US should adopt a more realistic restrained foreign policy. Noticeably, the United States concerned over the policy of remaking the world in its own image via spreading liberal democracy across the world, protecting human rights and enhancing an open international economy. However, the foreign policy directions took another path as the United States has turned to become a highly militarized state fighting wars that threaten the American

\footnotetext{
${ }^{2}$ Morgenthau Hans J. Politics among Nations: The Struggle for Power and Peace, Fifth Edition, (New York: Alfred A. Knopf, 1978)

${ }^{3}$ Beer, Francis A. and Robert Hariman. Post-realism, Just war, and the gulf war debate, in Meanings of War and Peace, (USA: Texas A\&M University Press, 2001), pp.2-3

${ }^{4}$ Waltz Kenneth. Theory of International Politics (New York: Random House, 1979) p.117

${ }^{5}$ Donnelly, Jack. Realism and International Relations (Cambridge: Cambridge University Press, 2000) p.8

${ }^{6}$ Waltz, Kenneth N.'Realist thought and neorealist theory', Journal of International Affairs, Vol. 44, No.1. (1990), pp. 21-37.
} 
liberal values ${ }^{7}$. According to classical realism, Great powers, as main actors in world politics, concerns about how much economic and military power they have comparing to the others. They pay attention to have substantial amount of power and at the same time seeking to prevent other state to markedly shift the balance of power in its favor. In other words, according to realists, international politics is synonymous with power politics ${ }^{8}$. In this context, Kenneth Waltz, one of neorealism's prominent supporters, argues that realism is still a valid theory to explain the international behaviors. He believes that the international political system has not changed profoundly enough to make the theory irrelevant. Hence, International interactions continue to depend on competition and thus he believes that the theory still preserving its power in describing and illustrating states actions in international order".

Virtually, human natures playing remarkable role in getting power against rivals and as a result the great powers are led by individuals who concentrate on keeping their state dominate in the power rivalry system. However, neo-realists or structural realists provide another approach to answer why states want power. Unlike classical realists who believe in human nature as driver for gaining more power, neo-realists perceived the structure of the international system as a motivation that urged states to pursue power at each other's expense. In the absence of centralized authority that stands above great powers, states seek to be powerful enough to protect itself against any potential attack. Therefore the system itself pushed states for power competition so as to survive in an anarchy system ${ }^{10}$.

As such, the lacking of common enforcing tools means that each state is responsible for its survival and therefore can define its interests and pursue efforts to gain power. Thus, the anarchy system has reinforced the role of power in determining states relations ${ }^{11}$. Neoclassical realism theory neglects cultural differences among states and type of regimes because the structure of international system provides the incentives for all powers to get more leverage vis-à-vis rivals. Therefore whether the regime is democratic or autocratic it matters little for states behaviors in foreign policy. In a related vein, it matters little also for who is responsible for conducting the state foreign policy which means that neo-realists look at states as if they were black boxes, albeit some states are more or less powerful than others. Defensive realists like Kenneth waltz points out that it is unwise for sates to maximize their power in seeking for hegemony because the system will punish them, meanwhile offensive realists like John Mearsheimer take different stance as he looks at gaining much power as something useful for states that pursue hegemony. This is not a statement that domination is favorable per se but rather having overwhelming power is the best option to maintain states own survival. Classical realists

\footnotetext{
${ }^{7}$ Mearsheimer John J. Great Delusion: Liberal Dreams and International Realities Kindle Edition, (Yale University Press, 2018)

${ }^{8}$ Mearsheimer John J. "Structural Realism," in Tim Dunne, Milja Kurki, and Steve Smith, eds., International Relations Theories: Discipline and Diversity, 2nd Edition (Oxford: Oxford University Press, 2010).p.78

${ }^{9}$ Waltz Kenneth N., 2000. Structural realism after the cold war: International Security, Vol. 25, No. 1 P.5.

${ }^{10}$ Mearsheimer, Op.cit.

${ }^{11}$ Dunne Tim et al. International Relations Theories, Discipline and Diversity (Oxford University Press, 2010)
} 
look at power as an end but structural realists conceived power as a means to achieve an end-that is survival ${ }^{12}$.

\section{The American Engagement in Arabia Strategic Interests}

The American relations with Arabia are focused primarily on importing oil with reduced prices from the gulf region that possess two-thirds of the world's known oil reserves. Saudi Arabia alone holds a quarter of the world's proven oil reserves ${ }^{13}$. As such, the US developing economy since 1970s drove to depend on the gulf to import oil and meet substantial domestic need. Moreover, the US depends also on exporting weapons to the GCC countries that spent hundreds of billions of dollars purchasing American military hardware. Noticeably, the Gulf oil has been envisaged as valuable resource for U.S. economy and therefore The U.S. policymakers engaged constantly in securing the oil supplies from the Gulf region into industrial world which requires American effective military posture in the region. Yet, this objective of securing the gulf continues as paramount priority in US strategy despite deep changes in global oil markets, critical development in U.S. internal energy production, and dramatic shifts in balance of power in the Middle East ${ }^{14}$. Interestingly, US voluminous geopolitical interests in Arabia are embodied, since more than 70 years, in securing the flow of oil without disruption from the region into the global economy through safeguarding the sea routes and keep them open for oil shipping. Other American concerns include counterterrorism; prevent acquisition of WMDs weapons; selling American weapons to the gulf allies and maintain the stability of the friendly regimes against any internal upheavals or regional encroachment. These objectives and concerns had intensified and deepened US bilateral relations with the ruling elites in the region. Therefore, Gulf security has been elevated to occupy top priority on the American foreign policy agenda. Hence, there is a conventional attitude of deep engagement in providing protection for a region that taking major role in providing the world energy market with oil upon which American and western prosperity depends ${ }^{15}$.

Importantly, US relations with Arab Gulf allies are pivotal and went beyond mutual economic advantages since the relations have been robustly intensified and the US had succeeded in establishing enduring and sustainable mutual relations. Obviously, the US continued military presence in the Gulf region proved effective in securing the sovereignty of pro-U.S. Arab governments in the Gulf. This was evident, for instance, in the wake of the Iranian Revolution in 1979 and after Iraq occupation of Kuwait in 1990. Evidently, the US geo-political and economic interests have contributed to strengthening

\footnotetext{
${ }^{12}$ Mearsheimer, Op.cit.

${ }^{13}$ Telhami, Shibley. The Persian Gulf: Understanding the American Oil Strategy, (The Brookings Institution, 2002). Available online under: https://www.brookings.edu/articles/the-persian-gulf-understanding-theamerican-oil-strategy/

${ }^{14}$ See Glaser Charles L. and Kelanic. Rosemary A. Editors, Rethinking the US Military Commitment to Defend Persian Gulf Oil, (Georgetown University Press, 2016)

${ }^{15}$ See Prados, Alfred B. Saudi Arabia: Current Issues and U.S. Relations. (Washington, D.C.: Congressional Research Service, 2003). p.1. See also Gause, III, F. Gregory, Saudi-American Relations, in The Kingdom of Saudi Arabia, 1979-2009: Evolution of a Pivotal State, (Washington, D.C, The Middle East Institute, 2009).
} 
the ties with the gulf regimes although it had experienced some tensions in the aftermath of 9/11 terrorist's events through which accusations had directed to Saudi Arabia for taking part in supporting terrorism. Also, the US and its gulf partner's relations had run into divergent visions in some instances and differences surfaced as to how regional politics should operate. This includes Iraq invasion, Obama's nuclear deal with Iran, Washington policy towards Arab-Israeli conflict, and the war on terrorism. However, the US continued to look at the Gulf Arabs as strategic advantages ${ }^{16}$. Saudi Arabia in particular has been conceived as a strategic partner in war against terrorism (Al Qaeda and ISIL terrorists sheltering in eastern Yemen, Iraq and Syria), cooperating with Washington with reference to conducting regional politics and managing security related policies. This demonstrates to large extent on realism approach that appears appropriate to describe, explain, and understand the US-Gulf relations that built based on mutual interdependence. As John Duke Anthony observes, "Over several decades and despite periodic tensions, U.S.-GCC relations have strengthened, broadened, and endured"17.

Realistically, solidifying and fostering the US relations with its gulf partners has been major goal in foreign policy for many decades, since first meeting between Franklin Roosevelt and King Abdulaziz Ibn Saud in 1945, with the objective of serving narrow US domestic interests in protecting oil resources, preventing nuclear proliferation and maintaining US leverage in the region. This materialized practically in preventing any regional power from emerge as effective power capable of threatening the US vital interests or targeting its allies ${ }^{18}$. This can be evidenced by American steady commitment to provide Gulf security through maintaining US military bases in the region with the purpose of keeping the balance of power in the US favor through deterring Iraq and Iran from gaining considerable leverage and destabilize the region. ${ }^{19}$

\section{US Preponderance and Maintaining Regional Security}

Indeed, American supremacy constitutes major objective in foreign policy since the end of the Cold $\mathrm{War}^{20}$. The US under G. W. Bush administration continued the American traditional attitudes for hegemony in the gulf. Bush, claimed, after September 11 trauma that U.S. military forces "will be strong enough to dissuade potential adversaries from pursuing a military build-up in hopes of surpassing, or equaling, the power of the United States." ${ }^{21}$ Similarly, the Obama administration, has emphasized this objective when it states that America "will continue to underwrite global security." Yet, it concentrates on

\footnotetext{
${ }^{16}$ Harb Imad K. The US and the GCC: A Steep Learning Curve for President Trump (Washington Arab Center, 2017). Available online under: http://arabcenterdc.org/policy_analyses/the-us-and-the-gcc-a-steep-learningcurve-for-president-trump/

${ }^{17}$ Anthony John Duke and Fahad Nazer, GCC-U.S. Relations Under a Trump Administration, the National Council on U.S.-Arab Relations, (2016). Available online under: https://ncusar.org/aa/2016/12/gcc-us-relationsunder-trump-administration/

${ }_{18}$ Miller Paul D. 'American Grand Strategy and the Democratic Peace', Survival: Global Politics and Strategy, vol. 54, no.2., (2012) p.15

${ }^{19}$ Pollack Kenneth M. A Series of Unfortunate Events: A Crisis Simulation of a U.S.-Iranian Confrontation (Brookings Institution, 2012). p.3

${ }^{20}$ See Hook, Steven W. and Tim Niblock, eds. The United States and the Gulf: Shifting Pressures, Strategies and Alignments (Berlin \& London: Gerlach Press, 2015)

${ }^{21}$ The US National Security Strategy, 2002: 30
} 
renewing American leadership to protect US interests ${ }^{22}$. Simultaneously, the Trump recent National Security Strategy that released on December 2017 emphasizes this traditional role by concentrating on Advancing American Influence in the world ${ }^{23}$.

The Obama administration initiated some economic changes and the policy of "pivoting Asia" meant that the president was seeking to strengthen the American bilateral trade cooperation with Asia. Nonetheless, it continued the traditional role in providing the gulf security to protect energy supply to the international market within reasonable prices. As such, America continued to play remarkable and decisive role in gulf regional affairs under successive American administrations and this role seems to continue in the foreseeable future as alternatives are not crystalized yet. Obviously, despite the biggest trade transactions between Saudi Arabia, UAE, China, and India, it is true that China and India looing to enhancing their relations with the Gulf governments in hydrocarbons realm and they are capitalizing on the gulf markets to promote their exports. Therefore, elevating this economic relationship to include military role in providing security to Arabia is unlikely to happen in the foreseeable future. ${ }^{24}$

President George W. Bush advocated a liberal world order in the wake of the 9/11 trauma to achieve gulf security. President Barack Obama believed in a vision to bring stability to the region through bringing Iran into the security structure and therefore he negotiated with Iran resulting in the Iran nuclear deal. However, the Trump policy revives the US basic objectives in Arabia materialized in securing the oil flow from the region into the world economy, protecting the security of Israel, holding Iran in check, and fighting terrorism and network terrorists ${ }^{25}$. Overall, the US engagement with Arabia are still encompassing myriad of security issues including Iran's hegemonic project and its increasing influence over Iraq, Iraq political and security development, weapons of mass destruction, counterterrorism, and safeguarding oil resources.

\section{Political Reform}

It is obvious that building up a liberal hegemonic order is a core principle in the US foreign policy for decades based on wide perception of the exceptionalism of the American political system and its validity to be promoted in the Middle East and the Gulf region $^{26}$. As Ikenberry notes, the US has been playing the role of "liberal leviathan" based on two pillars; power dominance and liberal principles of governance ${ }^{27}$. However,

${ }^{22}$ Ibid., 2010: 1

23 Ibid., 2017: 37

${ }^{24}$ Niblock, Tim, Yang Guang. Security Dynamics of East Asia in the Gulf Region (Berlin \& London: Gerlach Press, 2014). See also Hook, Steven W. and Tim Niblock, eds. The United States and the Gulf: Shifting Pressures, Strategies and Alignments (Berlin \& London: Gerlach Press, 2015).

${ }^{25}$ Cook, Steven A. Trump's Middle East Strategy Is Totally Boring, Foreign Policy, (2018). Available at: http://foreignpolicy.com/2018/02/21/trumps-middle-east-strategy-is-totally-boring/

Access date: 27 February, 2018

${ }^{26}$ Ikenberry, G. John et al. The Crisis of American Foreign Policy: Wilsonianism in the Twenty-First Century (USA: Princeton University Press, 2011a). See also Ikenberry, G. John. Liberal Order and Imperial Ambition: Essays on American Power and International Order (London: Polity Press, 2006).

${ }^{27}$ Ikenberry, G. John. Liberal Leviathan: The Origins, Crisis, and Transformation of the American World Order (New Jersey: Princeton University Press, 2011b). p.7 
this liberal order has always had primacy over ideological discourse for initiating genuine political reform in concerned states.

Ostensibly, promoting democracy in the Middle East in general and in Arabia in particular has been elevated to held prominent place on under the Bush administration foreign policy agenda. Indeed, 9/11 events contributed widely to a adopt freedom as a method that could from US standpoint help in eradicating terrorism. Clearly, the Bush administration conceived promoting democracy and political reform as overarching theme of the US foreign policy. The National Security Strategy of 2002 emphasizes this goal as it begins: "We fight, as we always fight, for a just peace-a peace that favors liberty". ${ }^{28}$ The US-led invasion of Iraq in 2003 could be explained with the context of changing the regional environment to be more secure through enhancing democracy and toppling the rogue regimes militarily that would eventually from Washington point of view contribute to eliminate violence and drying up the source of terrorist networks. Nevertheless, the realist approach continued to be predominant in US foreign policy calculations with reference to the relations with the allies in the gulf. Hence, despite the rhetoric on political reform, Bush has pursued a realist approach even in the freedom agenda and therefore he eschewed pressures on gulf governments to initiate and conduct deep/genuine political reform especially when Iraq after the invasion turn to become complete fiasco that contributed to breeding more violence, insecurity and radicalism.

Noticeably, favoring freedom continued to be part of US foreign policy under the Obama administration, as articulated clearly in the National Security Strategy of 2010, which states: "America's commitment to democracy, human rights, and the rule of law are essential sources of our strength and influence in the world". ${ }^{29}$ Clearly, the Bush policies in Iraq had resulted in unwanted and unexpected repercussions on regional security as it led to destabilize Iraq, breeding more terrorism and empowering Iran to become more influential in Iraq domestic affairs. Given the bad consequences of Bush adventure in Iraq (2003) and Afghanistan (2001), Obama did not practice real pressures on gulf regimes to embark on more steps towards political openings and instead maintained the Washington strategic relations with the gulf governments. However, these inclinations under both Bush and Obama to maintain US predominance in the international order through solidifying its liberal values have retreated under current Trump administration as he clearly downplayed and even neglected the notion of spreading American values $\operatorname{abroad}^{30}$.

In particular, it is important to note that realism has been directing overwhelmingly the American behaviors even in the realm of democracy. So, democracy has been perceived as proper instrument for maintaining US hard interests in the Gulf region. In other words, there was wide belief among successive American administrations that the development of liberal democracies in Arabia will, in the long term, advance American objectives in the region. ${ }^{31}$ Of particular interest to the above notions is the fact that despite the

${ }^{28}$ The US National Security Strategy, 2002: 1

${ }^{29}$ Ibid., 2010: 2

${ }^{30}$ See the National Security Strategy 2017

31 Wittes, Tamara Cofman. Freedom's Unsteady March: America's Role in Building Arab Democracy, (Washington D.C.: Brookings Institution Press, 2008); 2 
ideological rhetoric of democracy that had overemphasized during G. W. Bush administration, the US historical objectives in the gulf region remained dominant in US foreign policy. Bush himself has emphasized this pragmatism as he said, 'We support the advance of freedom in the Middle East, because it is our founding principle, and because it is in our national interest'. ${ }^{32}$ Therefore, the United States did not pursue the policy of promoting democracy as a blind ideological pledge; but rather it is a strategy that crafted to safeguard the U.S. interests. ${ }^{33}$

It can be argued that although the Bush administration vision in dealing with Arabia encompassed ideological aspects in terms of ratcheting up the importance of political reform values, he has pursued practical policy that has steered the genuine policies away of idealism. ${ }^{34}$ In other words, the Bush administration promotes democracy when it conforms to the US national interests but if proved practically that political reform clashes with those interests then the call for democratization has been downplayed or neglected in foreign policy. This explains explicitly the continuity of US hard interests as a determinant factor in shaping the foreign policy outcomes.

Apparently, the Trump new strategy provides differing approach towards democracy promotion from what Bush and Obama has advanced and advocated. It clearly states that "There is no arc of history that ensures that America's free political and economic system will automatically prevail". ${ }^{35}$ As such, The Trump's new National Security Strategy revives to large extent the US conventional foreign policy as it begins: "A strong America is in the vital interests of not only the American people, but also those around the world who want to partner with the United States in pursuit of shared interests, values, and aspirations". ${ }^{36}$ Trump new strategy challenges clearly the global strategy of both the Bush and Obama administrations when it states: "We are not going to impose our values on others. Our alliances, partnerships, and coalitions are built on free will and shared interests". ${ }^{37}$

Seemingly, The Trump National Security Strategy endorses a set of familiar values and actions. As such, the key ideas in Trump strategy echo prior central pillars in American National Security Strategies: "Protect the American People, the Homeland, and the American Way of Life"; "Promote American Prosperity"; "Preserve Peace through Strength"; and "Advance American Influence." ${ }^{38}$ Noticeably, the change that can be noticed in the American policy under Trump is that his strategy is not emphasizing the American traditional values of promoting liberalism and democracy while these values

32 Bush, George W. President George W. Bush Speaks at AEI's Annual Dinner (Washington D.C.: American Enterprise Institute, February 28, 2003). Available at:

http://www.aei.org/publication/president-george-w-bush-speaks-at-aeis-annual-dinner Access date: 15 November 2017.

${ }^{33}$ Lennon, Alexander T. J., Democracy in US security strategy: from promotion to support (Washington: CSIS, 2009), p.1

${ }^{34}$ Carothers, Thomas. U.S. Democracy Promotion During and After Bush, (Washington: Carnegie Endowment for International Peace, 2007), p.19

35 The US National Security Strategy 2017: 37

${ }^{36}$ Ibid: 1

${ }^{37}$ Ibid: 37

${ }^{38}$ Ibid. 
were overemphasized by the Bush administration especially in Iraq. Obama also was not seeking to reflect American values except in the ideational level- rhetorical sphere. Overall, if the president and his advisors show commitment to this strategy rigorously then the new approach would be largely traditional and realist. Hence, Despite Trump statements and rhetoric, his actual foreign policy turned out to be traditional and mostly looks like the mainstream views of other presidents. ${ }^{39}$

The US Secretary of State Rex Tillerson has clearly explained the Trump administration attitudes that lower the priority of democracy and human rights in US foreign policy. He states that promoting American values would not achieve the US national security goals and Interests, but rather this would probably "create obstacles to our ability to advance our national security interests, our economic interests". ${ }^{40}$

Contrary to some arguments that have seen Trump represents a real departure in US policy ${ }^{41}$, the basic message of Tillerson's recent trip to the Middle East, on February 2018, was that the "United States will privilege interests over values in the region". This, incidentally, represents neatly a stark continuation of the American past pattern and approach to the Middle East in the periods of 1980s and 1990s than some American scholars have come to expect. ${ }^{42}$

Noticeably, Trump statements and Obama strategic thinking have similarities and their messages are similar: "America must learn to step back from its previous global responsibilities". ${ }^{43}$ Obviously, what underlies the strategic thinking of both Barack Obama and Donald Trump is the realist approach that gives primacy of domestic affairs over foreign affairs. So, in 2011, Obama justified his decision to wind down the surge of US forces to Afghanistan stating that "the tide of war is receding" and asserting that "it is time to focus on nation-building here at home." 44

The realist approach of the Donald Trump administration materialized in his recent National Security Strategy through which he emphasizes that this strategy conforms to the narrow American internal interests. As he puts it: It is a strategy of principled realism

\footnotetext{
39 Jeffrey James F. The Trump National Security Strategy: Return to the Nineteenth Century? (Washington: The Washington Institute for Near East Policy, 2017).

40 Tillerson, Rex W. Remarks to U.S. Department of State Employees, (The US State Department, Washington, 2017), Available at:

https://www.state.gov/secretary/remarks/2017/05/270620.htm

Access date: 27 February, 2018

${ }^{41}$ Brands, Hal, Foreign Officials See Bush and Obama in Trump, Foreign Policy. (2018) Available at:

http://foreignpolicy.com/2018/02/23/foreign-officials-see-bush-and-obama-in-trump/

Access date: 27 February, 2018

${ }^{42}$ Cook, 2018

43 Donnelly, Thomas \& William Kristol. The Obama-Trump Foreign Policy, The Weekly Standard. (2018) Available at:

http://www.weeklystandard.com/the-obama-trump-foreign-policy/article/2011526

Access date: 28 February, 2018

${ }^{44}$ The White House. Remarks by the President on the Way Forward in Afghanistan, (2011), Available at:

https://obamawhitehouse.archives.gov/the-press-office/2011/06/22/remarks-president-way-forward-afghanistan Access date: 28 February, 2018
} 
that is guided by outcomes, not ideology. ${ }^{45}$ Moreover, he criticized in the new National Security Strategy the past presidents engagement in nation-building abroad and instead he focuses on building up nation at home. Hence, he emphasized domestic prosperity before international security. In Donnelly and Kristol words both presidents, Obama and Trump, are "America First" presidents. ${ }^{46}$ This policy seems reminiscent of past American approach over the last 70 years. The pragmatism of the foreign policy during both Obama and Trump extracted from their stance towards the American policy of promoting liberalization abroad. Indeed both presidents raised doubts about how this project could serve best the American interests. Trump puts it more blatantly: "The United States will forever be a great friend to the world, and especially to its allies. But we can no longer be taken advantage of, or enter into a one-sided deal where the United States gets nothing in return. As long as I hold this office, I will defend America's interests above all else". ${ }^{47}$ Simultaneously, Trump shares with his predecessors a more realistic approach through walking away from focusing on international harmony and replaces it with recognition of the competitive nature of power politics. As such, the promise of building an "empire for liberty" through promoting democracy project under both Obama and trump are downplayed in their foreign policy. ${ }^{48}$

Remarkably, Trump continues to address the challenges in the region including Iran as he pursues a new strategy that concentrates on tough policy towards Iran including enforcing robust mechanisms to prevent it from violating the nuclear deal. Moreover, Trump realistic attitudes can be extracted from actual policy of taking more hands-off approach with respect to domestic politics in the Arab Gulf States and minimizing Washington engagement on issues of human rights and political reforms. As such, some observers believe that Trump policy will "resurrect the golden age" of US-Gulf relations ${ }^{49}$ through the continuation of the American traditional strategic partnership and alliance with the ruling elites in Arabia. However, the US under Trump should intervene in the ongoing intra-GCC crisis as Saudi Arabia, the UAE, and Bahrain sieged Qatar since June 2017 and this would affect the gulf unity and impedes the efforts to contain Iran in the gulf.

\section{Conclusions}

The author has discussed the US engagement with Arabia in the period 2001-2018. To approach the study objectives Neorealism was used as theoretical framework that seems apposite to clarifying the US interactions with the region and through which the continuity of the realist tendencies in the American foreign policy were examined.

${ }^{45}$ The US National Security Strategy 2017: 1

${ }^{46}$ Donnelly \&Kristol, (2018)

${ }^{47}$ The White House, Remarks by President Trump to the 72nd Session of the United Nations General Assembly (2017), Available at:

https://www.whitehouse.gov/briefings-statements/remarks-president-trump-72nd-session-united-nationsgeneral-assembly/

Access date: 28 February, 2018

${ }^{48}$ Donnelly \& Kristol, (2018)

${ }^{49}$ Feierstein, Gerald. US-Gulf Relations in the Age of Trump: The End of the Trust Deficit. Policy focus 1/

(Washington: Middle East Institute, 2017) 
As can be gleaned from this research, the American foreign policy under the administrations of G.W. Bush, Barack Obama and Donald Trump either in enduring interests, security or political reform was largely realist and reflected the continuity of the previous longstanding policies. The study concludes that the US economic and geopolitical interests in Arabia had rooted deeply and extends for more than seven decades and therefore it had created solid foundations for mutual relationship and dependency between the US and its Gulf allies. As a result, Gulf security continued to preoccupy successive American administrations while planning foreign policy agenda and preserving Arabia remains, to this day, the cornerstone of the US interactions with the region.

Contrary to some arguments that conceived American foreign policy shifted from its traditional policy, this study argues that the US policy towards Arabia reflects a continuation of previous policies as appose to change. Evidently, the US national interests and geo-political concerns in Arabia have long been and remain to this day defined by conventional spectrum of objectives that have not changed dramatically under the administrations of Bush, Obama and Trump. However, the change that can be observed was relating to the tools that employed to achieve the US strategic interests. So, The Bush and Obama share a vision to the world that encapsulated endeavors to make sort of equilibrium between US grand strategic interests and moral values that reflect the American national identity. Remarkably, both presidents pursued practical realist policy that continued to rest on long-term strategic parameters in terms of preserving relations with the gulf ruling allies and defend the security of the region with an attempt to secure and serve the American economic and security objectives. In contrast, Donald Trump policy towards the gulf region represents so far a continuation of what has come before and has not departed drastically from US conventional policy. Having argued this, it is clear that the existence of US military force in the Gulf has contributed to the stability of pro-American gulf regimes. Besides, the military presence has led to deter the regional powers from any attempt to disrupt the flow of oil from the Gulf to the international markets. Overall America remains the balancing power in the Gulf and Appealing alternatives to the American security role in the Arabian Peninsula have not yet crystallized.

Furthermore, despite concentrating on promoting democracy in foreign policy agenda, there was no genuine political reform campaign in Arabia. Furthermore, the project of promoting American liberal values abroad which advocated by Bush and Obama administrations has been relinquished under current Trump administration. Trump eschewing advocacy for democracy and the New National Security strategy provides profound proof on the realist attitudes that have dominated in US foreign policy even in the democracy realm. The document reaffirms that American practical policy still stands on a spectrum of hard economic and geopolitical interests in the gulf region. Through clarifying the assumptions underlying the U.S. entanglement with the Gulf, the author concludes that the America's grand strategy towards the region is far stronger than is commonly assumed and doesn't change profoundly during the time frame of the study. 